Disease and Democracy 
1. The Corporate Practice of Medicine: Competition and Innovation in Health Care, by James C. Robinson

2. Experiencing Politics: A Legislator's Stories of Government and Health Care, by John E. McDonough

3. Public Health Law: Power, Duty, Restraint, by Lawrence O. Gostin

4. Public Health Law and Ethics: A Reader, edited by Lawrence O. Gostin

5. Big Doctoring: Profiles in Primary Care in America, by Fitzhugh Mullan, M.D.

6. Deceit and Denial: The Deadly Politics of Industrial Pollution, by Gerald Markowitz and David Rosner

7. Death Is That Man Taking Names: Intersections of American Medicine, Law, and Culture, by Robert A. Burt

8. When Walking Fails: Mobility Problems of Adults with Chronic Conditions, by Lisa I. Iezzoni

9. What Price Better Health? Hazards of the Research Imperative, by Daniel Callahan

10. Sick to Death and Not Going to Take It Anymore! Reforming Health Care for the Last Years of Life, by Joanne Lynn

11. The Employee Retirement Income Security Act of 1974: A Political History, by James A. Wooten

12. Evidence-Based Medicine and the Search for a Science of Clinical Care, by Jeanne Daly

13. Disease and Democracy: The Industrialized World Faces AIDS, by Peter Baldwin 


\title{
Disease and Democracy
}

The Industrialized World Faces AIDS

\author{
PETER BALDWIN
}

University of California Press

BERKELEY LOS ANGELES LONDON

Milbank Memorial Fund

NEW YORK 
The Milbank Memorial Fund is an endowed operating foundation that engages in nonpartisan analysis, study, research, and communication on significant issues in health policy. In the Fund's own publications, in reports or books it publishes with other organizations, and in articles it commissions for publication by other organizations, the Fund endeavors to maintain the highest standards for accuracy and fairness. Statements by individual authors, however, do not necessarily reflect opinions or factual determinations of the Fund.

University of California Press

Berkeley and Los Angeles, California

University of California Press, Ltd.

London, England

(C) 2005 by The Regents of the University of California

Library of Congress Cataloging-in-Publication Data

Baldwin, Peter.

Disease and democracy : the industrialized world faces AIDS / Peter Baldwin.

p. cm. - (California/Milbank books on health and the public; 13)

Includes bibliographical references and index.

ISBN 0-520-24350-1 (cloth : alk. paper)

1. AIDS (Disease)-Developed countries.

[DNLM: 1. Acquired Immunodeficiency Syndrome-prevention \& control. 2. Public Health Practice. 3. Democracy. 4. Developed Countries. 5. Disease Outbreaks-history. WC 503.6 B182d 2005] I. Title. II. Series.

RA643.8B35 $2004 \quad 2005$

362.196' 9792 'o091722-dc22 2004008793

Manufactured in the United States of America

$\begin{array}{lllllllll}13 & 12 & 11 & 10 & 09 & 08 & 07 & 06 & 05\end{array}$

$\begin{array}{llllllllll}10 & 9 & 8 & 7 & 6 & 5 & 4 & 3 & 2 & 1\end{array}$

The paper used in this publication meets the minimum requirements of ANSI/NISO z39.48-1992 (R 1997) (Permanence of Paper). 


\author{
For \\ John W. Baldwin \\ and \\ Jenny Jochens, \\ parents and colleagues
}


This page intentionally left blank 